PENGARUH PAPARAN ASAP ROKOK DENGAN BAHAN TAMBAHAN HERBAL TERHADAP LEUKOSIT DAN HISTOPATOLOGI PARU MENCIT (Mus musculus)

\title{
THE EFFECT OF EXPOSURE OF CIGARETTE SMOKE WITH HERB ADDITIVES ON LEUKOCYTE AND LUNG HISTOPATHOLOGY OF MICE (Mus musculus)
}

\author{
M Luthfi Ardiansyah ${ }^{1 *)}$, A.A.S.A.Sukmaningsih. ${ }^{\left.2^{* *}\right)}$, Saimul Laili ${ }^{3)}$ \\ ${ }^{123}$ Program Studi Biologi FMIPA Universitas Udayana Bali, Indonesia
}

\section{ABSTRAK}

Kebiasaan merokok sudah ada sejak jaman dahulu, tetapi dewasa ini kebiasaan tersebut dianggap sebagai hal yang merugikan terutama bagi kesehatan. Dampak yang sering dirasakan oleh para perokok adalah kesulitan dalam bernafas. Asap rokok mengandung sekitar $10^{15}-10^{17}$ oksidan atau radikal bebas, serta 4700 bahan kimia yang berbahaya, termasuk aldehid/carbonyls, $\mathrm{NO}_{2}$, dan $\mathrm{SO}_{2}$. Rokok herbal adalah rokok tembakau yang ditambahkan beberapa bahan dari tumbuhan. Rokok gurah herbal terapi sin merupakan rokok herbal yang dijual secara komersil. Tujuan penelitian ini adalah untuk mengetahui pengaruh rokok gurah terapi sin terhadap leukosit dan histologi paru-paru mencit. Penelitian ini menggunakan metode Komparatif yang terdiri atas 3 kelompok yaitu kontrol tidak dipaparkan asap rokok, perlakuan 1 dipaparkan asap rokok komersil dan perlakuan 2 dipaparkan asap rokok dengan kandungan herbal serta masing-masing kelompok terdiri dari 10 ulangan. Hasil penelitian menunjukkan bahwa terdapat perbedaan nyata $(\mathrm{p}<0,05)$ mengenai jumlah nekrosis sel, sel pneumosit tipe II, infiltrasi sel radang, hemoragi, dan pelebaran alveolus. Sedangkan hasil analisis mengenai jumlah leukosit menunjukkan perbedaan yang tidak nyata dimana $\mathrm{p}>0,05$ Hasil penelitian menunjukkan bahwa tidak ada perbedaan nyata pada jumlah leukosit kelompok kontrol, perlakuan 1 dan perlakuan $2(\mathrm{p}>0,05)$, Disimpulkan penggunaan rokok dengan tambahan bahan herbal yang mengandung berbagai macam antioksidan menyebabkan terjadinya kecenderungan perbedaan jumlah leukosit dimana terjadi penurunan jumlah limfosit serta neutrophil. Rokok dengan tambahan berbagai macam herbal menunjukka perbaikan struktur histopatologis paru terhadap nekrosis sel pneumosit tipe I, hemoragi, pelebaran alveolus, proliferasi sel pneumosit tipe II, dan infiltrasi sel radang dibandingkan pada mencit yang terpapar asap rokok komersil tanpa bahan herbal.

Kata kunci: asap rokok, sel darah putih, histopatologi, paru-paru

\begin{abstract}
Smoking habits have been around since ancient times, but nowadays this habit is considered to be detrimental, especially to health. The impact that is often felt by smokers is difficulty in breathing because the lungs are exposed to cigarette smoke. Cigarette smoke contains about $10^{15}-10^{17}$ oxidants or free radicals, as well as 4700 harmful chemicals, including aldehydes / carbonyls, $\mathrm{NO}_{2}$, and $\mathrm{SO}_{2}$. Herbal cigarettes are tobacco cigarettes with added ingredients from plants. Gurah terapi sin cigarettes are herbal cigarettes that are sold commercially. The aim of this study was to determine the effect of gurah cigarette smoking on the leukocytes and lung histology of mice. This study used a comparative method consisting of 3 groups, namely the control was not exposed to cigarette smoke, treatment 1 was exposed to commercial cigarette smoke and treatment 2 was exposed to cigarette smoke with herbal ingredients and each group consisted of 10 replications. The results showed that there were significant differences ( $p<0.05)$ regarding the number of cell necrosis, type II pneumocytes, inflammatory cell infiltration, hemorrhage, and alveolar dilation. While the results of the analysis of the number of leukocytes showed no significant difference where $p>0.05$. The results showed that there was no significant difference in the number of leukocytes in the control group, treatment 1 and treatment 2 ( $p>$

\footnotetext{
1) M Luthfi Ardiansyah, Universitas Udayana, Biologi FMIPA, Jl. Kampus Unud Jimbaran, Badung, Bali 80361

Telp. 081239732722. E-mail: hakimardiansyah6@ gmail.com

2) A.A.S A Sukmaningsih K, Universitas Udayana, Biologi FMIPA, Jl. Kampus Unud Jimbaran, Badung, Bali 80361

E-mail: Sukmaningsih@unud.ac.id
}

doi: 10.33474/e-jbst.v7i1.442

Diterima tanggal 13 Januari 2021- Diterbitkan Tanggal 31 Juli 2021 http://creativecommons.org/licenses/by/4.0 
0.05). herbs containing various kinds of antioxidants cause a tendency for differences in the number of leukocytes where there is a decrease in the number of lymphocytes and neutrophils and an improvement in the histopathological structure of the lung against type I pneumocyte cell necrosis, hemorrhage, alveolar dilation, type II pneumocyte cell proliferation, and inflammatory cell infiltration in exposed mice. commercial cigarette smoke without herbal ingredients.

Keywords: cigarette smoke, white blood cells, histopathology, lungs

\section{Pendahuluan}

Kebiasaan merokok sudah ada sejak jaman dahulu, tetapi dewasa ini kebiasaan tersebut dianggap sebagai hal yang merugikan terutama bagi kesehatan. Merokok merupakan salah satu aktivitas yang berpeluang mengganggu keseimbangan radikal bebas dan mekanisme pertahanan antioksidan dalam proses fisiologis tubuh yang normal. Menurut Kotzias dan Geiss (2007), asap rokok yang terhirup dan masuk ke dalam paru-paru akan mengakibatkan kanker, bronchitis, dan pneumonia.

Proses pembakaran rokok terdiri dari dua reaksi yakni reaksi pembakaran sempurna dan reaksi pirolisa. Reaksi pembakaran sempurna menyebabkan terbentuknya $\mathrm{CO}, \mathrm{CO}_{2}$, serta air karena proses pembakaran ini terjadi pada suhu $800^{\circ} \mathrm{C}$ yang terjadi pada ujung rokok yang memiliki kontak langsung dengan oksigen (Baker, 2006). Reaksi pirulisa terjadi pada suhu $200^{\circ} \mathrm{C}-600^{\circ} \mathrm{C}$ menyebabkan terjadinya pemecahan struktur kimia menjadi senyawa toksik (Angelis et al., 2014). Dilaporkan berbagai senyawa toksik seperti senyawa karsinogen, tar, nikotin, nitrosamin, karbon monoksida, senyawa PAH (Polynuclear Aromatic Hydrogen), fenol, karbonil, klorin dioksin dan furan (Fitriani et al., 2009).

Pembakaran biomassa rokok menghasilkan asap rokok yang merupakan aerosol padat atau cair yang terbentuk dari tetesan partikel. Asap rokok dibedakan menjadi asap utama (mainstream) dan asap sampingan (sidestream). Asap utama berupa TPM (total particulate matter) teridiri atas tar, nikotin dan air) dan fase gas. Asap sampingan terdiri dari fase gas dan fase padat. Partikel ultrafine asap rokok yang memiliki ukuran lebih kecil dari $100 \mathrm{~nm}$ merupakan partikel yang terinhalasi dapat mengalami deposisi dan berinteraksi dengan sel, pembersihan, dan translokasi melalui saluran pernafasan menuju paru-paru, alveoli, menembus pembuluh darah, dan masuk kedalam organ tubuh lainnya (Lin dkk., 2014). Partikel asap rokok mengandung berbagai jenis radikal bebas berupa supraoksida, hidroksil, hydroquinone (Valvanidis, dkk., 2009).

Partikel asap rokok yang masuk kedalam paru-paru dapat menyebabkan terjadinya respon inflamasi dan sebaliknya respon inflamasi dapat membentuk radikal bebas (Daher dkk, 2009). Penelitian Smith et al. (2005) meyatakan bahwa paparan rokok pada level kronis akan memicu reaksi inflamasi berulang pada sistem pernafasan terutama pada paru-paru. Inflamasi terjadi karena respon imun yang berlebih karena adanya antigen atau benda asing yang masuk ke dalam tubuh. Inflamasi muncul karena adanya infiltrasi limfosit $\mathrm{T}$, neutrofil dan makrofag pada saluran nafas. Selain itu terdapat pula ketidakseimbangan terhadap CD4 (helper) dan CD8 (sitotoksik). limfosit T sitotoksik (CD8) akan menginfiltrasi saluran nafas.

Beberapa penelitian menunjukkan bahwa upaya mengurangi resiko atau bahaya asap rokok dari radikal bebas dengan menggunakan berbagai bahan tanaman. Berbagai bahan herbal dapat menurunkan resiko bahaya pada asap rokok. Penggunaan pycnogenol, ekstrak biji anggur, dan lycopene pada filter dapat menurunkan radikal bebas pada asap rokok (Yu, dkk., 2012). Penggunaan pycnogenol secara in vivo pada tikus terbukti mengurangi mutagenesis yang terjadi pada eritrosit (Zhang et al., 2002). Pycnogenol, ekstrak biji anggur, dan lycopene yang di aplikasikan pada filter 
rokok mampu menurunkan radikal bebas asap rokok yang diuji dengan menggunakan Electron Spin Resonance (ESR). Penelitian yang dilakukan Sukmaningsih dkk (2019), menyatakan bahwa penggunaan ekstrak buah juwet pada filter rokok mampu mengurangi radikal bebas yang terdapat di dalam asap rokok.

Salah satu rokok komersial dengan berbagai tambahan herbal yaitu, siwak, madu, jinten hitam, cengkeh, jahe, kapulaga, kencur, ketumbar, daun sirih dan lada hitam telah digunakan secara umum di kalangan masyarakat tertentu di Indonesia. Kombinasi berbagai bahan herbal dipercaya dapat mengurangi radikal bebas yang terdapat di dalam asap rokok. Penelitian Zarai et al. (2013), menyatakan aktivitas antioksidan total ekstrak etanol lada hitam setara 48,2 ppm $\alpha$-tokoferol pada konsentrasi ekstrak $25 \mathrm{ppm}$. Senyawa piperin pada lada hitam Berdasarkan hal tersebut penelitian ini bertujuan mempelajari pengaruh rokok tersebut terhadap histopatologis paru dan jumlah leukosit pada mencit (Mus musculus). Eugenol pada cengkeh memiliki aktivitas antioksidan yang efektif memerangkap radikal bebas alkil $60 \%$, hidroksil 48,57 \%, dan peroksil 35,71\%, dan yang berkontribusi dalam memerangkap radikal bebas (Nujannah dkk, 2013). Penelitian Qonitah dan Ahwan (2018), menyatakan bahwa aktivitas antioksidan pada daun sirih sangat kuat dengan nilai IC50 sebesar 37,37 $\mu \mathrm{g} / \mathrm{mL}$.

\section{Material dan Metode}

\section{Bahan dan Alat}

Bahan yang digunakan dalam penelitian ini adalah pelet sentrat sebagai pakan, akuades, rokok dengan bahan herbal, rokok tanpa bahan herbal, mencit (Mus musculus) (umur; 2-3 bulan, BB; 25-30 gram), metanol 90\%, ketamine, xylazine, dan larutan formalin buffer.

Alat digunakan dalam penelitian ini kandang mencit, penutup kandang, botol minum mencit, timbangan digital, botol urin untuk organ, spite, sectio set, spuit, selang kecil, kotak pengasapan, handscoon, masker, pinset, dan bak parafin.

\section{Metode}

Penelitian ini telah mendapatkan Ethical Clearance/Keterangan Kelaikan Etik Nomor: 105/UN14.2.9./PT.01.04/2020, dari Fakultas Kedokteran Hewan Universitas Udayana, Denpasar, Bali. Penelitian ini menggunakan metode Rancangan Acak Lengkap (RAL) dengan sampel berjumlah 30 ekor mencit jantan berusia 2-3 bulan, serta berat berkirsar 25-30 gram dibagi kedalam 3 kelompok secara acak masing-masing 10 ekor. Kelompok kontrol merupakan mencit tanpa perlakuan paparan asap rokok. Kelompok perlakuan 1 (R1) merupakan mencit yang diberikan perlakuan paparan asap rokok kretek tanpa bahan herbal dengan kandungan nikotin 2,3 mg dan 32 mg TAR. Kelompok perlakuan 2 (R2) merupakan mencit dipaparkan asap rokok kretek komersil menggunakan berbagai tambahan herbal dengan kandungan 0,09 mg nikotin dan 48,08 mg TAR. Berbagai tambahan herbal pada rokok ini adalah adalah siwak, madu, jinten hitam, cengkeh, jahe, kapulaga, kencur, ketumbar, daun sirih dan lada hitam. 
e-Jurnal Ilmiah BIOSAINTROPIS (BIOSCIENCE-TROPIC)

Volume : 7/ No. : 1 / Halaman 118-130 / Januari Tahun 2021

ISSN : 2460-9455 (e) - 2338-2805(p)

\section{Cara Kerja}

Aklimatisasi hewan coba: Mencit dengan berat badan 25 gram sd 30 gram dibagi secara acak dan dimasukkan ke dalam 3 buah kandang plastik dengan tutup menggunakan kawat besi. Masing-masing kandang berisi 9 ekor mencit kemudian diadaptasikan selama satu minggu, hal ini dilakukan agar mencit dapat menyesuaikan diri terhadap lingkungan yang baru. Pakan yang diberikan berupa pellet sentrat, pemberian pakan dan minum diberikan secara ad libitum. Selain itu kondisi kandang diusahakan dalam keadaan bersih.

Pemberian perlakuan: Pengasapan dilakukan dengan menggunakan 3 kotak pengasapan. Kotak pengasapan yang digunakan berukuran panjang $35 \mathrm{~cm}$, lebar $18 \mathrm{~cm}$, dan tinggi $20 \mathrm{~cm}$ pada kedua sisi kotak diberi lubang untuk memasukkan rokok dan sebagai ventilasi. Masing-masing kotak pengasapan berisi 1 ekor mencit dan diberikan 1 batang rokok dilakukan selama 30 hari. Pengasapan dilakukan menggunakan alat Smoking Pump. Setelah rokok habis, mencit dibiarkan di dalam kotak pengasapan selama 10 menit atau sampai asap yang berada di kotak pengasapan hilang dengan membuka penutup kotak. Kemudian mencit dikeluarkan dari kotak pengasapan dan diletakkan kembali ke dalam kandang pemeliharaan (Sukmaningsih, 2019). Pada akhir perlakuan dilakukan penimbangan berat badan mencit.

Pembedahan Hewan coba: Mencit akan dikorbankan pada hari ke-31 dengan cara diinjeksi menggunakan ketamine dengan dosis $80-100 \mathrm{mg} / \mathrm{kg}$ dan xylazine dengan dosis $10 \mathrm{mg} / \mathrm{kg}$. Dilakukan koleksi terhadap darah dan organ paru.

Pemeriksaan sampel darah: Darah diambil melalui ventrikel jantung dan ditampung ke dalam tabung vacutainer yang sudah berisi larutan EDTA, selanjutnya dilakukan pemeriksaan terhadap leukosit menggunakan alat Hematology Analyzer.

Pembuatan sediaan histologi: Pembuatan sediaan histopatologi paru dilakukan menggunakan metode parafin. Larutan fiksatif yang digunakan adalah formalin buffer. Pewarnaan yang digunakan adalah Hematoxylin-Eosin. Pengamatan histologi menggunakan mikroskop yang terhubung dengan Opti Lab (Muntiha, 2001).

Analisis data: Variabel yang diamati adalah jumlah leukosit meliputi limfosit, monosit, eosinofil, neutrofil dan basofil. Variabel yang diamati pada organ paru-paru meliputi, pelebaran alveolus, Hemoragi, nekrosis, sel pneumosit tipe II, dan infiltrasi sel radang. Data yang diperoleh dari penelitian ini dianalisa menggunakan Analysis of Variance (ANOVA) menggunakan program SPSS versi 24. 
e-Jurnal Ilmiah BIOSAINTROPIS (BIOSCIENCE-TROPIC)

Volume : 7/ No. : 1 / Halaman 118-130 / Januari Tahun 2021

ISSN : 2460-9455 (e) - 2338-2805(p)

\section{Hasil dan Diskusi}

\section{Hasil Penelitian}

Berdasarkan hasil analisis data dengan One Way Anova, maka didapatkan hasil berat badan dan parameter kerusakan paru-paru pada penelitian ini sebagai berikut:

Tabel 1. Hasil analisis statistik rata-rata berat badan mencit

\begin{tabular}{cccc}
\hline & \multicolumn{3}{c}{ Kelompok } \\
\cline { 2 - 4 } Berat Badan Awal & $33,50 \pm 0,86^{\mathrm{a}}$ & Perlakuan 1 & Perlakuan 2 \\
Berat Badan Akhir & $33,79 \pm 1,49^{\mathrm{a}}$ & $33,06 \pm 0,47^{\mathrm{a}}$ \\
\hline
\end{tabular}

Keterangan: Huruf yang sama pada masing-masing kolom menunjukkan hasil yang tidak berbeda nyata ( $\mathrm{p}$ $>0,05)$

Berdasarkan Tabel 1, hasil berat badan pada penelitian ini memiliki nilai tidak berbeda nyata $(\mathrm{p}>0,05)$. Hal ini menunjukkan bahwa tidak terdapat perbedaan antar kelompok kontrol, perlakuan 1 dan perlakuan 2 .

Tabel 2. Hasil analisis statistik rata-rata leukosit mencit

\begin{tabular}{cccc}
\hline & \multicolumn{3}{c}{ Kelompok } \\
\cline { 2 - 4 } & $\begin{array}{c}\text { Kontrol } \\
(/ \mu \mathrm{l})\end{array}$ & $\begin{array}{c}\text { Perlakuan } 1 \\
(/ \mu \mathrm{l})\end{array}$ & $\begin{array}{c}\text { Perlakuan } 2 \\
(/ \mu \mathrm{l})\end{array}$ \\
\cline { 2 - 4 } Monosit & $6,90 \pm 4,33^{\mathrm{a}}$ & $6,70 \pm 4,62^{\mathrm{a}}$ & $6,80 \pm 5,65^{\mathrm{a}}$ \\
Limfosit & $43,00 \pm 26,92^{\mathrm{a}}$ & $43,10 \pm 28,88^{\mathrm{a}}$ & $40,30 \pm 30,84^{\mathrm{a}}$ \\
Neutrofil & $30,10 \pm 22,16^{\mathrm{a}}$ & $30,20 \pm 23,80^{\mathrm{a}}$ & $22,00 \pm 22,27^{\mathrm{a}}$ \\
Basofil & $00,00 \pm 00,00^{\mathrm{a}}$ & $00,00 \pm 00,00^{\mathrm{a}}$ & $00,00 \pm 00,00^{\mathrm{a}}$ \\
Eosinofil & $00,00 \pm 00,00^{\mathrm{a}}$ & $00,10 \pm 00,10^{\mathrm{a}}$ & $00,00 \pm 00,00^{\mathrm{a}}$ \\
\hline
\end{tabular}

Keterangan: Huruf yang sama pada masing-masing kolom menunjukkan hasil yang tidak berbeda nyata $(\mathrm{p}>$ $0,05)$ 
e-Jurnal Ilmiah BIOSAINTROPIS (BIOSCIENCE-TROPIC)

Volume : 7/ No. : 1 / Halaman 118-130 / Januari Tahun 2021

ISSN : 2460-9455 (e) - 2338-2805(p)

Berdasarkan Tabel 2, jumlah monosit, limfosit, dan neutrofil pada penelitian ini menunjukkan perbedaan tidak nyata $(\mathrm{p}>0,05)$.

Tabel 3. Hasil analisis statistik rata-rata kerusakan organ paru mencit

\begin{tabular}{cccc}
\hline & \multicolumn{3}{c}{ Kelompok } \\
\cline { 2 - 4 } & Kontrol & Perlakuan 1 & Perlakuan 2 \\
\cline { 2 - 4 } $\begin{array}{c}\text { Nekrosis sel } \\
\text { pneumosit tipe I }\end{array}$ & $4,48 \pm 1,52^{\mathrm{a}}$ & $21,96 \pm 3,08^{\mathrm{b}}$ & $18,44 \pm 3,30^{\mathrm{c}}$ \\
Sel pneumosit tipe II & $2,82 \pm 0,73^{\mathrm{a}}$ & $17,37 \pm 1,89^{\mathrm{b}}$ & $13,05 \pm 2,00^{\mathrm{c}}$ \\
Infiltrasi sel radang & $1,82 \pm 0,61^{\mathrm{a}}$ & $25,26 \pm 1,28^{\mathrm{b}}$ & $16,70 \pm 1,28^{\mathrm{c}}$ \\
Hemoragi & $2,17 \pm 1,35^{\mathrm{a}}$ & $17,00 \pm 4,88^{\mathrm{b}}$ & $12,87 \pm 2,36^{\mathrm{c}}$ \\
Pelebaran alveolus & $39,72 \pm 6,92^{\mathrm{a}}$ & $62,75 \pm 8,38^{\mathrm{b}}$ & $63,36 \pm 8,18^{\mathrm{c}}$ \\
\hline
\end{tabular}

Keterangan: Huruf yang berbeda pada masing-masing kolom menunjukkan hasil yang berbeda nyata $(\mathrm{p}<0,05)$

Tabel 4. Kategori kerusakan organ paru mencit

\begin{tabular}{cccc}
\hline & & Kelompok & \\
\cline { 2 - 4 } Nekrosis sel & Kontrol & Perlakuan 1 & Perlakuan 2 \\
\cline { 2 - 4 } pneumosit tipe I & Ringan & Ringan & Ringan \\
Sel pneumosit tipe II & Ringan & Ringan & Ringan \\
Infiltrasi sel radang & Ringan & Ringan & Ringan \\
Hemoragi & Ringan & Ringan & Ringan \\
Pelebaran alveolus & Sedang & Parah & Parah \\
\hline
\end{tabular}

(Katherine et al, 2013)

Berdasarkan Tabel 3, hasil uji statistik didapatkan nilai $\mathrm{p}=0,000(\mathrm{p}<0,05)$. Hal ini menunjukkan bahwa terdapat perbedaan yang berarti antar kelompok kontrol, perlakuan I dan perlakuan II. Tabel 4 memperlihatkan 4 parameter mengalami tingkat kerusakan ringan dan 1 parameter mengalami tingkat kerusakan sedang dan parah

\section{Pembahasan}

Berdasarkan hasil yang didapat, terdapat kecenderungan penurunan berat badan pada kelompok rokok komersial meskipun secara analisis statitistik tidak menunjukkan adanya perbedaan berat badan. Nikotin dianggap sebagai penahan nafsu makan dengan meningkatkan kadar gula dalam darah. Peningkatan kadar gula darah akan menstimulasi insulin untuk dikeluarkan dari pankreas. Insulin diyakini memiliki efek mengenyangkan, hormon kolesitokinin disebut juga sebagai satiety signal untuk menekan rasa lapar (Barasi, 2009). Partikel asap rokok yang masuk ke dalam paru-paru merupakan partikel ultrafine (Lin dkk, 2014). Partikel ultrafine mengandung radikal bebas yang dapat menimbulkan respon imun. Sel imun yang berperan 
adalah leukosit. Leukosit merupakan bagian dari respon imun tubuh terhadap zat asing salah satunya adalah radikal bebas.

Salah satu respon imun pada tubuh adalah inflamasi. inflamasi dapat mempengaruhi jumlah leukosit yang dikeluarkan. Inflamasi pada organ pernafasan menginduksi marker inflamasi seperti sitokin yang akan mempengaruhi jumlah leukosit (Malenica et al., 2017). Proses inflamasi dapat menghasilkan radikal bebas karena adanya peningkatan polimorfonuklear leukosit saat proses fagositosis (Arnson et al., 2010).

Hasil analisis statistik leukosit pada tabel 2. menunjukkan tidak adanya perbedaan yang nyata (nilai $p>0,05$ ) tetapi terjadi kecenderungan penurunan leukosit pada perlakuan 2 . Hal ini terjadi karena kandungan antioksidan yang tedapat pada rokok dengan bahan herbal. Hal tersebut mengindikasikan bahwa antioksidan yang terkandung pada rokok herbal mampu membantu leukosit melawan radikal bebas (Maulana dkk, 2019). Antioksidan dibutuhkan oleh tubuh untuk melindugi tubuh dari radikal bebas yang masuk. Antioksidan akan menyediakan elektron bagi radikal bebas sehingga tidak merusak keseimbangan elektron di dalam sel sehat. Pada saluran pernafasan lapisan epitel merupakan komponen utama yang melakukan kontak dengan substansi yang ikut terhirup seperti asap rokok dan polutan lainnya yang berada di udara (Kania, 2014).

Partikel asap rokok menginduksi respon inflamasi pada organ paru yang diinisiasi oleh makrofag alveolar dan sel epitel saluran udara. Makrofag memiliki potensi untuk memproduksi mediator pro-inflamasi. Makrofag alveolar dan sel epitel paru akan membentuk pertahanan ketika partikel asap rokok masuk ke dalam tubuh (Holgate et al., 2000). salah satu ciri respon inflamasi pada penelitian ini adalah dengan adanya infiltrasi sel radang yang umumnya didominasi oleh neutrofil.

Inflamasi yang terjadi karena paparan asap rokok berdampak pula pada kerusakan organ paru. Pada tabel 4 kerusakan organ paru dikategorikan ringan dan hasil analisis statistik pada penelitian ini menunjukkan hasil yang berbeda antar kelompok dengan nilai $\mathrm{p}<0,05$. Perbedaan nyata terjadi pada kelompok kontrol dan perlakuan I dimana mencit dipaparkan asap rokok komersil tanpa adanya tambahan bahan herbal yang terkandung di dalamnya. Hasil pembakaran rokok tersebut menyebabkan stres oksidatif yang berakibat kerusakan pada muccociliary clearance (Sela et al., 2004). Penggunaan bahan herbal berupa siwak, madu, jinten hitam, cengkeh, jahe, kapulaga, kencur, ketumbar, daun sirih dan lada hitam pada perlakuan II (R2) menunjukkan perbaikan terhadap perubahan histopatologis paru. Hal tersebut sesuai dengan penelitian mengenai penggunaan ekstrak buah juwet pada filter rokok.

Analisis dengan menggunakan ESR menunjukkan rokok dengan filter ekstrak buah juwet mampu menurunkan intensitas radikal bebas asap rokok (Sukmaningsih,dkk 2019). Ekstrak buah juwet diketahui mengandung berbagai bahan antioksidan seperti anthocyanin . (Sukmaningsih dkk, 2018)

Kerusakan organ paru menyebabkan proses peningkatan respon imun dalam mengeluarkan zat dan partikel asing. Sehingga menimbulkan infeksi dan inflamasi pada paru (Sun et al., 2014). Mitchell et al. (2009), menyatakan partikel asing yang masuk ke dalam alveolus menyebabkan respon peradangan. Saat proses peradangan terjadi aktivasi dan fagositosis oleh sel leukosit membebaskan ROS, serangkaian proses tersebut mengakibatkan terjadinya akumulasi makrofag dan neutrofil di alveolus.

Sel pneumosit tipe 2 bertanggung jawab atas produksi dan sekresi surfaktan serta bertanggung jawab atas elastisitas paru-paru (Khaira, 2010). Sel pneumosit tipe 2 dapat bereplikasi dan menggantikan sel pneumosit 1 apabila mengalami kerusakan. Proliferasi sel 
pneumosit tipe 2 menjadi indikator adanya kerusakan pada alveolus (Junqueira and Carneiro, 2009). Sel pneumosit tipe 2 memiliki sensitivitas yang tinggi terhadap zat asing yang masuk ke dalam paru-paru. Proliferasi sel pneumosit tipe 2 merupakan respon adanya trauma di dalam paru-paru (Honda et al., 2003).

Kerusakan lain yang terlihat adalah adanya pelebaran alveolus. pelebaran alveolus bersifat kronis dan progresif sehingga dapat menjadi indikasi bahwa seseorang tersebut memiliki gejala penyakit paru obstruktif kronis (Suryadinata, 2018). Umumnya pelebaran pada alveolus merupakan ciri dari emfisema. Emfisema merupakan kerusakan pada paru-paru yang menyebabkan rusaknya kantung udara dan hilangnya elastisitas. Salah satu yang menyebabkan hilangnya elastisitas pada alveolus adalah asap rokok. Penderita emfisema memiliki volume paru yang lebih besar karena karbon dioksida yang seharusnya di keluarkan tetapi terperangkap di dalam alveolus. Tubuh tidak mendapatkan oksigen yang cukup, sehingga menyebabkan sesak nafas (Wynimko, J.C., 2016).
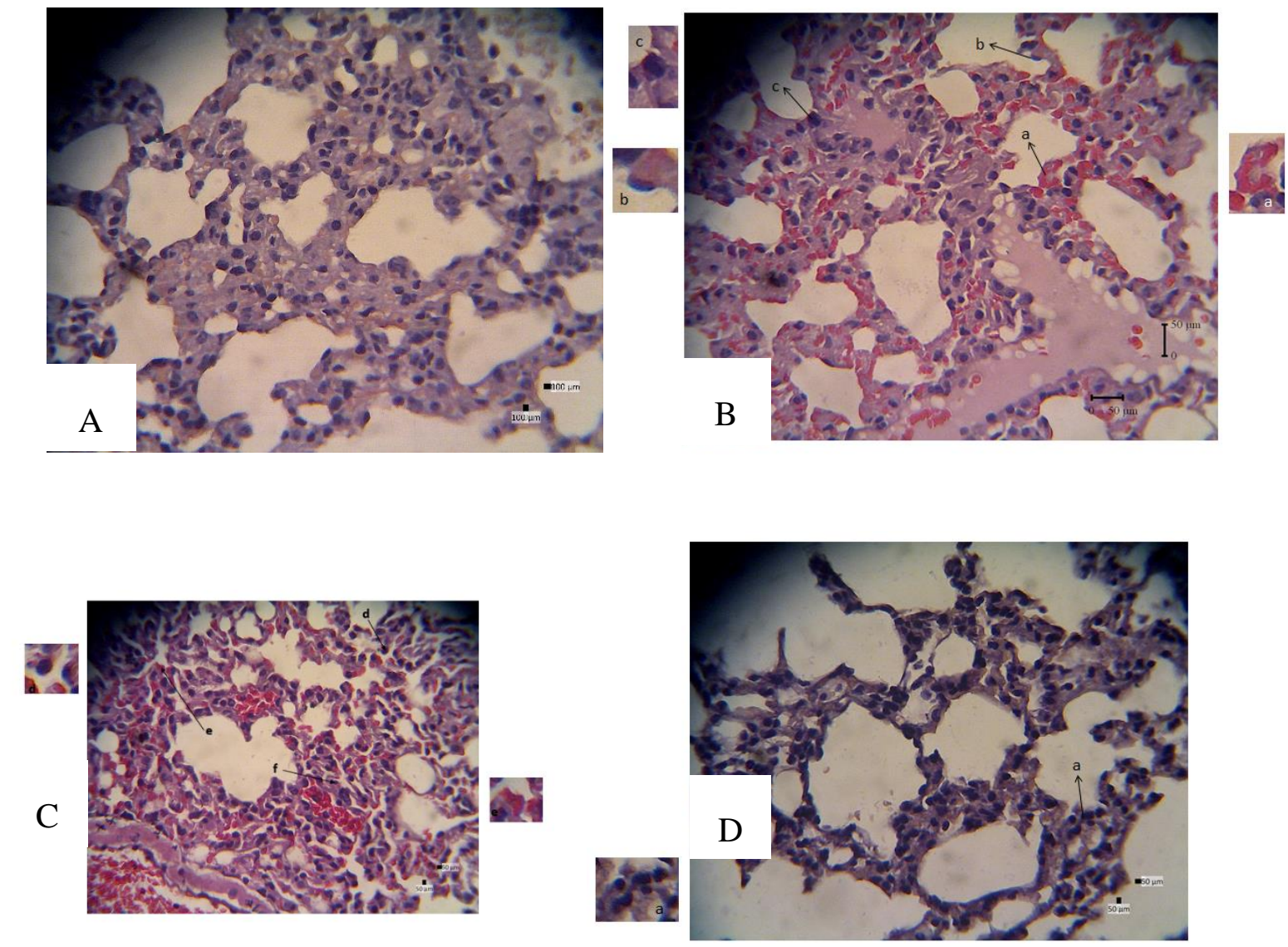

Gambar 1. Gambaran mikroskopis organ paru mencit

Pewarnaan : Hematoksilin-Eosin

Perbesaran : 400X

Keterangan: (A)Kontrol, (B) R1 dipaparkan asap rokok komersil ((a) hemoragi, (b) nekrosis sel,

(c) infiltrasi sel radang), (C) R2 dipaparkan asap rokok gurah terapi sin ((d) nekrosis sel, (e) hemoragi, (f) infiltrasi sel radang), (D) sel pneumosit tipe II 
Gambar 1 menunjukkan adanya infiltrasi sel radang yang terjadi pada jaringan. Neutrofil merupakan sel radang yang paling pertama bereaksi dengan sinyal yang dikeluarkan oleh sel rusak pada organ paru (Rahmawandani, 2013). Penyakit pada organ paru dapat diakibatkan dari beberapa hal, salah satunya adalah asap rokok. Penyakit yang disebabkan oleh asap rokok antara lain bronkitis, emfisema, dan bronkiolitis. Ciri yang sering dirasakan oleh penderita penyakit tersebut adalah kesulitan bernafas. Hal tersebut terjadi ketika asap rokok yang menjadi salah satu radikal bebas masuk ke dalam paru yang mengakibatkan kematian sel dan terjadinya reaksi inflamasi.

Kematian pada sel pneumosit tipe 1 (Gambar 1) disebabkan oleh radikal bebas yang masuk ke dalam paru. Sel pneumosit tipe 1 yang rentan terhadap zat toksik akan mengalami kematian dan tidak dapat melakukan replikasi sehingga akan digantikan oleh sel pneumosit tipe 2 yang lebih kuat dan dapat bereplikasi (Honda et al., 2003).
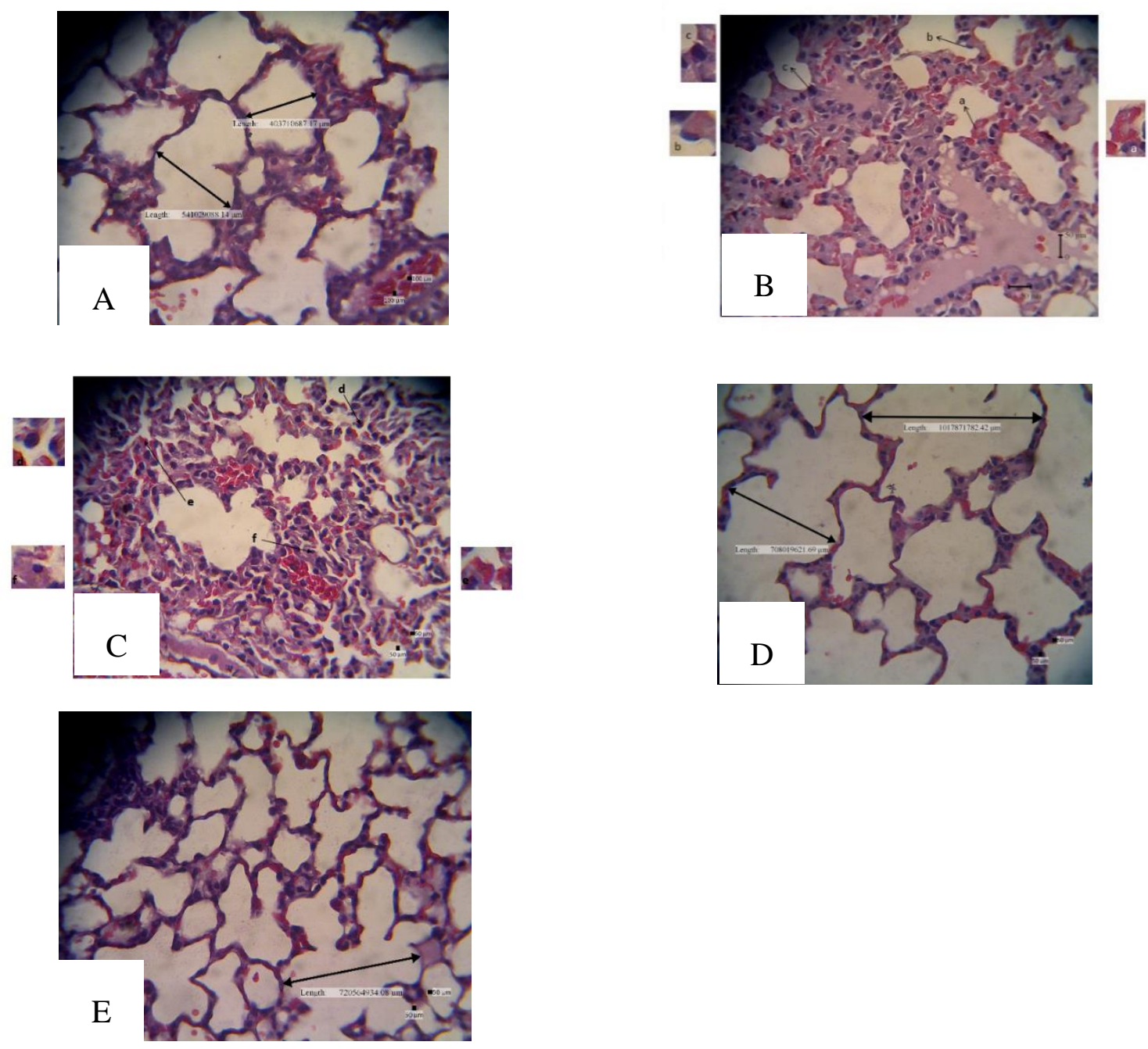

Gambar 2. Gambaran mikroskopis histopatologi organ paru mencit Pewarnaan : Hematoksilin-Eosin Perbesaran : 400X

Keterangan: (A) Kontrol, (B) R1 dipaparkan asap rokok komersil, (C) R2 dipaparkan asap rokok gurah terapi sin, (D) R1 pelebaran alveolus, (E) R2 pelebaran alveolus 
e-Jurnal Ilmiah BIOSAINTROPIS (BIOSCIENCE-TROPIC)

Volume : 7/ No. : 1 / Halaman 118-130 / Januari Tahun 2021

ISSN : 2460-9455 (e) - 2338-2805(p)

Gambar 2 menunjukkan kerusakan pada jaringan paru yaitu kantung alveolus yang melebar atau yang sering disebut emfisema terjadi karena hilangnya pembatas antara alveoli dengan duktus alveoli karena adanya kematian sel atau apoptosis sel (Masruroh dkk, 2014). Pelebaran alveolus menjadi tanda penyakit emfisema. Pelebaran alveolus pada penelitian ni dikategorikan sedang hingga parah. Selain karena asap rokok, pelebaran alveolus disebabkan karena faktor genetik dan faktor eksternal yaitu debu, asap kendaraan dan asap hasil pembakaran sampah (Herdman, 2010).

\section{Kesimpulan}

Berdasarkan hasil penelitian ini, maka dapat disimpulkan bahwa, penggunaan rokok dengan tambahan bahan herbal yang mengandung berbagai macam antioksidan menyebabkan terjadinya kecenderungan perbedaan jumlah leukosit dimana terjadi penurunan jumlah limfosit serta neutrofil dan perbaikan struktur histopatologis paru terhadap nekrosis sel pneumosit tipe I, hemoragi, pelebaran alveolus, proliferasi sel pneumosit tipe II, dan infiltrasi sel radang pada mencit yang terpapar asap rokok komersil tanpa bahan herbal.

\section{Ucapan Terima Kasih}

Terima kasih kepada PT. Tridaya Sinergi Indonesia karena telah membantu penulis dengan memberikan dukungan bahan rokok herbal yang digunakan dalam penelitian.

\section{Daftar Pustaka}

[1] Kotzias, D and O. Geiss. 2007. Tobacco, Cigarettes and Cigarettes Smoke. European Commission Directorate-General Joint Research Centre Institute For Health and Consumer Protection. European Communities

[2] Baker, R. R. 2006. Smoke Generation Inside a Burning cigarette : Modifying Combustion to Develop Cigarettes That May be Less Hazardous to Health. 375-385

[3] Angelis, N., K. Propodis., P. Zarogoulidis., D. Spyratos., I. Kioumis., A. Papaiwannouw and G. Pitsiouw. 2014. Airway Inflammation in Chronic Obstructive Pulmonary Disease. Journal Thorac. Dis. 6 : 4-9

[4] Fitriani., K. Eriani., W. Sari. 2009. The effect of cigarettes smoke exposured causes fertility of male mice (Mus musculus). Jurnal Natural. 10(2) : 1-6.

[5] Lin, B., X. Li., H. Zhang., Z. Lin., L. Tian., C. Nie and Z. Xi. 2014. Comparison of In Vitro Toxicity of Mainstream Cigarette Smoke Particulate Matter From Nano- to 
e-Jurnal Ilmiah BIOSAINTROPIS (BIOSCIENCE-TROPIC)

Volume : 7/ No. : 1 / Halaman 118-130 / Januari Tahun 2021

ISSN : 2460-9455 (e) - 2338-2805(p)

Micro- Size. Food and Chemical Toxicology: An International Journal Published for the British Industrial Biological Research Association. 64 : 353-360

[6] Valvanidis, A., T. Vlachogiani and K. Fiotakis. 2009. Tobacco Smoke: Involvement of Reactive Oxygen Species and Stable Free Radicals in Mechanisms of Oxidative Damage, Carcinogenesis and Synergistic Effects with Other Respirable Particles. International Journal of Enviromental Research and Public Health. 6(2) : 445-462. DOI: $10.3390 /$ ijerph6020445

[7] Daher, N., R. Saleh, E. Jaroudi, H. Sheheitli, T. r. s. Badr, E. Sepetdjian, M. A. Rashidi, N. Saliba dan A. Shihadeh. 2009. Comparison of carcinogen, carbon monoxide, and ultrafine particle emissions from narghile waterpipe and cigarette smoking: Sidestream smoke measurements and assessment of secondhand smoke emission factors. Atmospheric Environment: 1-2. DOI: 10.1016/j.atmosenv

[8] Smith, K.R., K.E. Pinkerton., T. Watanabe., T.L. Pedersen., S.J. Ma and B.D. Hammock. 2005. Attenuation of Tobacco Smoke-Include Lung Inflammation by Treatment With a Soluble Epoxide Hydrolase Inhibitor. Journal Pharmacology. 102(6) : 2186 - 2191. DOI: $10.1073 /$ pnas.0409591102

[9] Yu, L., B. G. Dzikovski dan J. H. Freed. 2012. A Protocol for Detecting and Scavenging Gas-phase Free Radicals in Mainstream Cigarette Smoke. 1-5. DOI: $\underline{10.3791 / 3406}$

[10] Zhang, D., Y. Tao., J. Gao., C. Zhang., S. Wan., Y. Chen., X. Huang., X. Sun., S. Duan., F. Schonlau., P. Rohdewald and B. Zhao. 2002. Pycnogenol In Cigarette Filters Scavenger Free Radicals and Reduce Mutagenicity and Toxicity of Tobacco Smoke in Vivo. Toxicology and Industrial Health. 18(5) : 215224. DOI: $\underline{10.1191 / 0748233702 \text { th145oa }}$

[11] Sukmaningsih, A.A.S.A., S. Permana., D.J.D.H. Santjojo., A.Y.P. Wardoyo dan S.B. Sumitro. 2019. The Potency of Java Plum (Syzygium cumini) Fruit Extract as Free Radical Scavenging in Cigarette Smoke. AIP Conference Proceeding. 1-6. DOI: $\underline{10.1063 / 1.5125519}$

[12]_Muntiha, M. 2001. Teknik Pembuatan Preparat Histopatologi dari Jaringan Hewan dengan Pewarnaan Hematoksilin dan Eosin. Balai Penelitian Veteriner. Bogor.

[13] Katherine N., G.Corley, K.O. Alicia, and D.K. Meyerholz. 2013. Principles For Valid Histopathologic Scoring In Research. Vet Pathol. 50(6)

[14] Barasi, M. E. 2009. At a Glance Ilmu Gizi (H. Halim, Trans). Erlangga Medical Series. Jakarta 
e-Jurnal Ilmiah BIOSAINTROPIS (BIOSCIENCE-TROPIC)

Volume : 7/ No. : 1 / Halaman 118-130 / Januari Tahun 2021

ISSN : 2460-9455 (e) - 2338-2805(p)

[15] Malenica, M., B. Prnjavorac., T. Bego., T. Dujic., S. Semiz., S. Skrbo., AGusic., A. Hadzic and A. Causevic. 2017. Effect of Cigarette Smoking on Haematological Parameters in Healthy Population. Medical Archives. 71(2) : 132-136 DOI: $10.5455 /$ medarh.2017.71.132-136

[16] Arnson, Y., Y. Shoenfeld and H. Amital. 2010. Effect of Tobacco Smoke on Immunity, Inflamation and Autoimmunity. Journal of Autoimmunity. 34(3) : 258-265 DOI: $10.1016 /$ j.jaut.2009.12.003

[17] Maulana, I., H. I. Wahyuni dan T. Yudiarti. 2019. Pengaruh Penambahan Ekstrak Tomat Sebagai Air Minum Terhadap Profil Darah Putih Ayam Broiler yang Diinfeksi Bakteri E. coli. Jurnal UNS. 3(1) : 34-41

[18] Kania, N. 2014. Pathobiologi Molekuler Paru. PT. Grafika Wangi Kalimantan. Kalimantan

[19] Holgate, S.T., P. Lackie., S. Wilson., W. Roche and D. Davies. 2000. Bronchial epithelium as a key regulator of airway allergen sensitization and remodeling in $\begin{array}{llllll}\text { asthma. } A m ~ & J & \text { Respir }\end{array}$ DOI: 10.1164/ajrccm.162.supplement_2.ras-12

[20] Sela, S., Shurtz-Swirski, R., Awad, J., Shapiro, G., Nasser, L and S.M. Shasha. 2004. The Involvement of Peripheral Polymorphonuclear Leukocytes in the Oxidative Stress and Inflammation among Cigarette Smokers. Israel Medical Association Journal. 4(11) : 1015-1019. DOI: 10.1681/ASN.2004110929

[21] Sukmaningsih, A.A.S.A, S. Permana., D.J.D.H. Santjojo., A.Y.P. Wardoyo dan S.B. Sumitro. 2018. Investigating Natural Transition Metal Coordination Anthocyanin Complex In Java Plum (Syzygium cumini) Fruit as Free Radical Scavenging. Rasayan J. Chem. 11(3) : 1193-1203. DOI : 10.31788/RJC.2018.1133047

[22] Sun, Y., S. Ito., N. Nishio., Y. Tanaka., N. Chen and K.I. Isobe. 2014. Acrolein induced both pulmonary inflammation and the death of lung epithelial cells. Toxicology Letters. 229(2) : 384-392. DOI: 10.1016/j.toxlet.2014.06.021

[23] Mitchell, R.N., V. Kumar., A.K. Abbas and N. Fausto. 2009. Antioxidant Activity of Medical and Aromatic Plants a Review. Flavour Fragr Journal. 25(29) : 291-312

[24] Khaira, K. 2010. Menangkal Radikal Bebas Dengan Anti-oksidan. Jurnal Saintek. 2(2) : 183-187

[25] Junqueira, Luis.C and J. Carneiro. 2009. Histologi Dasar. Edisi 10. EGC. Jakarta 
e-Jurnal Ilmiah BIOSAINTROPIS (BIOSCIENCE-TROPIC)

Volume : 7/ No. : 1 / Halaman 118-130 / Januari Tahun 2021

ISSN : 2460-9455 (e) - 2338-2805(p)

[26] Honda T, Ota H, Yamazaki Y, Yoshizawa A, Fujimoto K, and Sone S. 2003. Proliferation of type II pneumocytes in the lung biopsy specimens reflecting alveolar damage. Respir Med. 97(1): 80-85. DOI: 10.1053/rmed.2002.1408

[27] Suryadinata, R.V. 2018. Pengaruh Radikal Bebas Terhadap Proses Inflamasi pada Penyakit Paru Obstruktif Kronis (PPOK). Jurnal Sains. 2(1) : 37-324 DOI: $\underline{10.20473 / a m n t . v 2 i 4.2018 .317-324}$

[28] Wynimko, J.C. 2016. Disease modification in emphysema related to alpha-1 antitrypsin deficiency. Taylor and Francis Group. 1(1) : 1-9. DOI: $\underline{10.1080 / 15412555.2016 .1178224}$

[29] Rahmawandani, F.I. 2013. Studi Patologi Kasus Kolibasilosis Pada Babi Landrace Berdasarkan Umur. Denpsar. FKH Universitas Udayana: [Skripsi].

[30] Masruroh, L., U. P. Juswono dan A. Y. P. Wardoyo. 2014. Pengaruh Emisi Partikel Ultrafine Asap Pembakaran Biomassa Terhadap Organ Paru-Paru Mencit (Mus musculus) Berdasarkan Gambaran Mikroskopisnya. Brawijawa Physics Student Journal. 1-4

[31] Herdman, H. 2010. Diagnosa keperawatan. EGC. Jakarta

[32] Nurjannah, D.A., R. Retnowati dan U. P. Juswono. 2013. Aktivitas Antioksidan dari Minyak Cengkeh (Syzygium aromaticum) Kering Berdasarkan Aktivitas Antiradikal yang Ditentukan Mengguanakan Electron Spin Resonance. Kimia Student Journal. $1(2): 283-288$

[33] Qonitah, F dan Ahwan. 2018. Aktivitas Antioksidan dan Kandungan Fenolik Total dari Isolat Polar Fraksi Heksana Ekstrak Etanol Daun Sirih (Piper betle L.). Jurnal Farmasetis. 7(1) : 42-46

[34] Zarai, Z., E. Boujelbene., N.B. Salem., Y. Gargouri and A. Sayari. 2012. Antioxidant and antimicrobial activities of various solvent extracts, piperinae and piperic acid from Piper nigrum. LWT - Food Sci Technol. 50(2):634-641. 